\title{
Hypoxia in obesity - from bench to bedside
}

\author{
Jianping Ye \\ From 2012 Sino-American Symposium on Clinical and Translational Medicine (SAS-CTM) \\ Shanghai, China. 27-29 June 2012
}

It is generally accepted that hypoxia is related to sleep apnea in obesity. This concept has been changed since the report of hypoxia response in adipose tissue of obese mice by our group in 2007 [1]. The observation has been confirmed by many laboratories in multiple obesity model systems including mouse and human [2-8]. The adipose tissue hypoxia has been a new concept to explain the adipose tissue dysfunction in obesity $[9,10]$. It provides a unified answer to all of the pathological changes in the adipose tissue under obesity, such as chronic inflammation, ER stress, leptin expression, adiponectin reduction, adipocyte death, elevated lipolysis and adipocyte insulin resistance $[9,10]$. Studies suggest that capillary dysfunction occurs during expansion of adipose tissue $[11,12]$, and leads to reduction in adipose blood supply [13], which is responsible for the tissue hypoxia. In this aspect, the adipose tissue dysfunction is a result of local vascular failure in obesity [13]. In addition, the hypoxia-induced inflammation response has beneficial effects in the body. For example, inflammatory response stimulates adipose tissue remodeling $[11,14]$ and promotes energy expenditure to fight against obesity $[15,16]$. These new insights into the adipose tissue biology suggest that the hypoxia response may be a feedback mechanism in the protection of body against obesity. In translation of this view into clinical setting, it is believed that sleep apnea is also a protection mechanism in the body to maintain energy homeostasis in obesity. It uses the hypoxia response to trigger the onset of multiple protection mechanisms in the body.

Published: 17 October 2012
References

1. Ye J, Gao Z, Yin J, He H: Hypoxia is a potential risk factor for chronic inflammation and adiponectin reduction in adipose tissue of ob/ob and dietary obese mice. Am J Physiol Endocrinol Metab 2007, 293:E1118-E1128.

2. Hosogai N, Fukuhara A, Oshima K, Miyata Y, Tanaka S, Segawa K, Furukawa S, Tochino $Y$, Komuro R, Matsuda M, et al: Adipose tissue hypoxia in obesity and its impact on adipocytokine dysregulation. Diabetes 2007, 56(4):901-911.

3. Greenstein AS, Khavandi K, Withers SB, Sonoyama K, Clancy O, Jeziorska M, Laing I, Yates AP, Pemberton PW, Malik RA, et al: Local inflammation and hypoxia abolish the protective anticontractile properties of perivascular fat in obese patients. Circulation 2009, 119(12):1661-1670.

4. Yin J, Gao Z, He Q, Ye J: Role of hypoxia in obesity-induced disorders of glucose and lipid metabolism in adipose tissue. Am J Physiol Endocrinol Metab 2009, 296:E333-E342.

5. Rausch ME, Weisberg S, Vardhana P, Tortoriello DV: Obesity in C57BL/6J mice is characterized by adipose tissue hypoxia and cytotoxic T-cell infiltration. Int J Obes (Lond) 2008, 32(3):451-463.

6. Pasarica M, Sereda OR, Redman LM, Albarado DC, Hymel DT, Roan LE, Rood JC, Burk DH, Smith SR: Reduced adipose tissue oxygenation in human obesity: evidence for rarefaction, macrophage chemotaxis, and inflammation without an angiogenic response. Diabetes 2009, 58(3):718-725.

7. Pasarica M, Rood J, Ravussin E, Schwarz JM, Smith SR, Redman LM: Reduced oxygenation in human obese adipose tissue is associated with impaired insulin suppression of lipolysis. The Journal of clinical endocrinology and metabolism 2010, 95(8):4052-4055.

8. Zhang L, Ebenezer PJ, Dasuri K, Fernandez-Kim SO, Francis J, Mariappan N, Gao Z, Ye J, Bruce-Keller A, Keller JN: Aging is associated with hypoxia and oxidative stress in adipose tissue: Implications for adipose function. American journal of physiology-Endocrinology and metabolism 2011, 301(4): E599-E607.

9. Ye J: Emerging Role of Adipose Tissue Hypoxia in Obesity and Insulin Resistance. Int J Obes 2009, 33(1):54-66.

10. Trayhurn P, Wang B, Wood IS: Hypoxia in adipose tissue: a basis for the dysregulation of tissue function in obesity? Br J Nutr 2008, 1-9.

11. Pang C, Gao Z, Yin J, Zhang J, Jia W, Ye J: Macrophage Infiltration into Adipose Tissue May Promote Angiogenesis for Adipose Tissue Remodeling in Obesity. Am J Physiol Endocrinol Metab 2008, 295 : E313-E322.

12. Gealekman O, Guseva N, Hartigan C, Apotheker S, Gorgoglione M, Gurav K, Tran KV, Straubhaar J, Nicoloro S, Czech MP, et al: Depot-Specific Differences and Insufficient Subcutaneous Adipose Tissue Angiogenesis in Human Obesity. Circulation 2011, 123(2):186-194.

13. Ye J: Adipose Tissue Vascularization: Its Role in Chronic Inflammation Current diabetes reports 2011, 11(3):203-210.

14. Halberg N, Khan T, Trujillo ME, Wernstedt-Asterholm I, Attie AD, Sherwani S, Wang ZV, Landskroner-Eiger S, Dineen S, Magalang UJ, et al: HIF 1 alpha Induces Fibrosis and Insulin Resistance in White Adipose Tissue. Mol Cell Biol 2009, 29(16):4467-4483.

Correspondence: yej@pbrc.edu

Antioxidant and Gene Regulation Laboratory, Pennington Biomedical Research Center, Louisiana State University System, Baton Rouge, Louisiana 70808, USA

5. Tang T, Zhang J, Yin J, Staszkiewicz J, Gawronska-Kozak B, Mynatt R, Martin RJ, Keenan M, Gao Z, Ye J: Uncoupling of Inflammation and Insulin 
Resistance by NF-kB in Transgenic Mice through Induction of Energy Expenditure. J Biol Chem 2010, 285:4637-4644

16. Jiao P, Feng B, Ma J, Nie Y, Paul E, Li Y, Xu H: Constitutive Activation of IKK $\beta$ in Adipose Tissue Prevents Diet-Induced Obesity in Mice.

Endocrinology 2012, 153(1):154-165.

doi:10.1186/1479-5876-10-S2-A20

Cite this article as: Ye: Hypoxia in obesity - from bench to bedside.

Journal of Translational Medicine 2012 10(Suppl 2):A20.

Submit your next manuscript to BioMed Central and take full advantage of:

- Convenient online submission

- Thorough peer review

- No space constraints or color figure charges

- Immediate publication on acceptance

- Inclusion in PubMed, CAS, Scopus and Google Scholar

- Research which is freely available for redistribution

Submit your manuscript at www.biomedcentral.com/submit 